\title{
Essays
}

\section{On the Meaning of Congressional Silence: Using Federal Common Law To Fill the Gap in Congress's Residual Statute of Limitations}

\author{
Abner J. Mikva ${ }^{\dagger}$ and James E. Pfander ${ }^{\dagger \dagger}$
}

Of the many gaps in the scheme of federal law, few have so vexed the federal judiciary as those that result when Congress creates a federal cause of action but fails to specify a period of limitations to govern the timeliness of the suit. ${ }^{1}$ Such congressional omissions have occurred with monotonous regularity and frequently confound the judicial branch: The federal courts have struggled in recent years to supply the measures of timeliness that Congress left out of the civil rights laws of 1871 , the

$\dagger$ Judge (Ret.). District of Columbia Circust Coun of Appeals, Visıng Professor of Lew und Walter V. Schaefer Scholar, University of Chicago Law School. The numbered footnotes cite cases and supporung material. Cf. Abner J. Mikva, Goodbye to Footmotes, 56 U CoLo L REV 647 (1985) (advocating the use of footnotes in judicial opinions to cite supporung authonty and not to funher a discusstun of malters properly addressed in the text).

$\frac{i t}{}$ Professor of Law, University of Illinols College of Law We want to thank Chules Geyh, Enc Lane, Debby Merrit, Katherine Nelson, Kim Norwood. Sieve Ross. Cass Sunstein, and the laculty workshop at the College for helpful comments on previous drafts We dedicate this Essuy to Sarah. Samantha, Benjamin, and especially to Laurie.

1. See Federal Courts Study Comninee Implementanon Act and Cwul Justuce Reforn Act Hearngs on H.R. 5381 and H.R. 3898 Before the Subcomm. on Courts. Intellectual Propern. and the Admustranon of Justice of the House Comm. on the Judicion; 101st Cong $146(1990)$ [hereinafter Hearings] (stutement of Deanell R. Tacha, Circuit Judge, U.S. Coun of Appeals for the Tenth Circuit) ("I think that I can safely speak on behalf of all Federal judges in the Nation who have groped for the appropnste State statule ot limitations to apply. I, the Judicial Conference, and most of the judges $I$ know suppon the propusal that a Federal statute of limitations be provided for laws which do not atherwise provide $\&$ stalute ol limitations."); see also Tellis v. United States Fidehty \& Guar Co. 805 F 2d 7\$1. 747 (7th Cir 1986) (Ripple, J., dissenting) (decrying the "tedious" process of borrowing a gapfiller trom stalte law), sacated. 483 U.S. 1015 (1987).

2. See 42 U.S.C. $\$ \S 1983,1985-1986$ (1994) Couns borrow state law to guvern the umeliness of $\$$ 1983 claims under the influence of $\$ 1988$, which provides for the determination of clams under the ctw! rights statutes "in conformity with the laws of the United States" and, in cases where those laus do not speak, in accordance with "the common law. . and statutes of the Siale so tat ds the same is not inconsistent with" federal law. 42 U.S.C. \$ 1988 (1994) The Coun has made an ellun to develop a 
securities law of $1934,{ }^{3}$ and the plant closing legislation of $1988 .{ }^{4}$ Such judicial struggles reflect in part the amorphous nature of the gapfilling process. Under the standard learning, federal courts supply omitted time limits by borrowing the most analogous statute of limitations from state law. ${ }^{5}$ When, as often happens, a good many analogous state statutes present themselves, federal judges must make a choice from among plausible alternatives. ${ }^{6}$ Judges understandably chafe under the burden of choosing statutes of limitations, particularly in light of the judicial perception that Congress ought to assume primary responsibility for fixing limitations periods. ${ }^{?}$

Judicial efforts to shift the task of setting limits to Congress culminated in the 1990 report of the Federal Courts Study Committee, recommending that Congress establish particular time limits for all existing federal causes of action. $^{8}$ Although Congress responded in part with the passage of the Judicial Improvements Act of $1990,{ }^{9}$ the provision dealing with limitations periods

workable limitations period for $\$ 1983$ claims. Compare Wilson v. Garcia, 471 U.S. 261, 265-66 (1985) (resolving a conflict among the lower federal courts over the proper characterization of civil rights claims arising under $\S 1983$ and holding that federal courts should borrow the most analogous state limitations period for personal injury claims), with Owens v. Okure, 488 U.S. 235, 249-50 (1989) (resolving a further division over which personal injury limitations period to apply to $\$ 1983$ claims and establishing a presumption in favor of the state's fallback or "residual" statute of limitations).

3. See Securities Exchange Act of 1934, 15 U.S.C. \$\$ 78a-781l (1994); see ctsu Lampi, Pleva, Lipkind, Prupis \& Petigrow v. Gilbertson, 501 U.S. 350, 361 (1991) (applying a limitations period drawn from federal securities laws as the measure of the timeliness of the implied private right of action for insider trading).

4. See Worker Adjustment and Retraining Notification (WARN) Act, 29 U.S.C. $\$ \$ 2101-2109(1994)$; see also North Star Steel Co. v. Thomas, 515 U.S. 29, 35 (1995) (resolving a circuit split by borrowing state limitations periods as the measure of the timeliness of claims arising under the WARN Acl)

5. See North Star Steel, 515 U.S. at 34 (describing the practice of relying upon state law as the primary source of borrowed limitations periods for federal rights of action as "Iongstanding" and "scltled" (quoting Agency Holding Corp. v. Malley-Duff \& Assocs., 483 U.S. 143, 147 (1987); Wilson, 471 U.S. at 266).

6. See Shon v. Belleville Shoe Mig. Co., 908 F.2d 1385, 1394 (7th Cir. 1990) (Posner, J., concurring) (identifying eight factors that might inlorm the choice of limitations periods and characterizing the process as an exercise of "standardless, discretionary judgment" that defies predictability and necessitates litigation).

7. See Tellis v. United States Fidelity \& Guar. Co., 805 F.2d 741, 747 (7th Cir. 1986) (Ripple, J.. dissenting) (declaring that "IITixing the statute of limitation for a particular cuuse of action is a legislative function"), vacated, 483 U.S. 1015 (1987); Moviecolor Ltd. v. Eastman Kodak Co., 288 F.2d 80, 83 (2d Cir. 1961) (maintaining that the "selection of a period of years lis not / the kind of thing judges do"); spe" also Halkias v. General Dynamics Corp., 31 F.3d 224, 248 (5th Cir. 1994) (Wisdom, J., disscnting) (characterizing the process of borrowing as "so tenuous in loundation it appears as but an ateademic exercise"), vacated, 56 F.3d 27 (1995), aff'd, 101 F.3d 698 (1996); Short, 908 F.2d at 1393 (Pusincr, J., concurring) (likening the borrowing process to detcrmining "which round peg to stull in a scjuare hole").

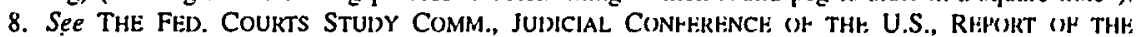
FEDERAL COURTS STUdY COMMITTEE 93 (1990) [hercinafler RhPORT]. Congress created the Federal Courts Study Committce in legislation adopted in 1988 and directed it to study and report on such millers as altemative dispute resolution, the resolution of conflicts in judicial authority, and federal court structure and administration. See id. at 31 . Members of the Commuttec, appoinled by the Chicl Justice of the Uniled States in December 1988, included representalives from the three branches of the federal government and from state governments, universitics, and private legal practice. Ste idl.

9. Pub. L. No. 101-650, 104 Stat. 5089 (1990) (codified in sciltered sections of 28 U.S.C. (1994)). The residual federal limitations period now codified in title 28 appears in one part of that Act, known as the Implementation Act, Pub. L. No. 101-650. tit. III, $\$ 313($ a), $1(24$ Stat. 5104, 5114-15 (1990) (codilico at 28 U.S.C. \& (658). 
stopped well short of the recommendation. Now codified as $\$ 1658$ of title 28 , the relevant provision simply states, "Except as otherwise provided by law, a civil action arising under an Act of Congress enacted after the date of enactment of this section may not be commenced later than 4 years after the cause of action accrues."10 Section 1658 thus establishes a fallback or residual limitations period for claims arising under statutes enacted after December 1 , $1990,{ }^{11}$ but remains silent as to what periods of limitation should govern the more than two hundred express and implied rights of action arising under statutes already in existence on the date of the legislation (i.e., preenactment federal statutes). ${ }^{12}$

Judges and academic commentators generally view $§ 1658$ 's silence about the timeliness of claims arising under such preenactment statutes as a serious gap in the new law. Federal judges who restified before the House Subcommittee recognized that $\S 1658$ does not directly address the period of limitations for the "myriad" of existing federal rights of action; they criticized what they saw as Congress's decision to force judges to "contunue to grope"13 for an analogous state limitations period to borrow. Leading academic accounts of the section agree with this judicial criticism, ${ }^{14}$ porraying Congress as having failed to discharge its legislative function and arguing for further legislation to fill the gap in $\S 1658 .^{15}$ The decisional law points in the same direction: Federal courts that have faced such questions since 1990 have generally continued to determine the timeliness of clams arising under preenactment statutes by following the established state law borrowing mode; the courts have uniformly rejected arguments for reliance on the four-year limitations period of $\S 1658$ as an appropriate measure of the timeliness of such existing rights of action. ${ }^{16}$

10. 28 U.S.C. $\$ 1658$.

11. See id.

12. Following the passage of $\$ 1658$, the slaft of the House Subcommilee sted the Nitunal Luth Center of the George Washington University to conduct a surney of existing lederal limutations lash and recommend legislation to close the gap left by $\$ 1658$ Prolessor Peler Rasen-Hansen cunducted the survey in question and proposed a four-year statute of limitations 10 gosem all existing ledetal clatus Sre Petcr Raven-Hansen, The Federal Statute of Limitions Act of 1992 (Feb 14. 1992) (unpublished manusuript, on file with authors). Among other things, Raven-Hansen's study idenutites ovef 560 express and implied rights of action, only about 350 of which are limited by specific statutes of limitation See al at 3

13. Hearings, supra note 1 , at 146 (statement of Deanell R Tachs. Circull Judg̣e. L"S Cinun of Appeals for the Tenth Circuit); see also id. at 92 (stalement of Juseph F Wiss. Jt. Sestor Circult Judge. U.S. Court of Appeals for the Third Circuit) (expressing hope thal adoption of the partial solution propused by the House Committe would not derall congressional review of exisung limutalius problems and characterizing recourse to state limitations penods as gapfillers as "A generally "sstetul excefcise")

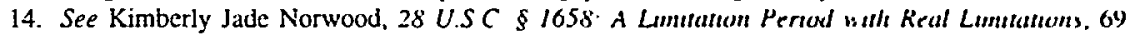
IND. L.J. 477 (1994); see also Kathanne F Nelson. The 1990 Federal "Fallowith 'Stature of Lamulatous Limitations by Default, 72 NEB. L. REV 454 (1993). M1 Patrich McDuncll. Nute, Lamututson Pertosls for

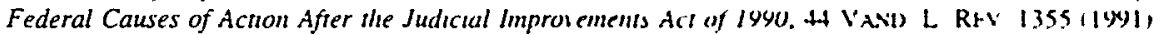

15. See Norwood, supra note 14, at 503-08. 517-18. see also Nelson, supra nute 14, at 505.07. 514 (critictzing Congress's falure to address the tumeliness of rights of dituon existing as of Decenter ivy) and urging further legislation to address the problem). McDowell. supra nute 14. at 1355.54 (5ank)

16. The federal courts have refused to apply $\$ 1658$ 's four-year hmutanons penixl to clams ansing 
In this Essay, we contend that $\S 1658$ may go further to solve the problem of the timeliness of federal claims than others have assumed. Although the statute does not by its terms establish a limitations period for claims arising under preenactment federal statutes, federal courts can reliably exercise their common-lawmaking powers to borrow the four-year residual period of $\S 1658$ as the limitations period for many such claims. Congress did not freeze in place a regime of state law borrowing. Rather, Congress left the selection of judge-made limitations periods to the flexible process of making federal common law. Federal courts should modify the relevant body of federal common law to establish a rule of presumptive reliance on periods drawn from federal law. In particular, federal courts should seriously consider borrowing the $\S 1658$ four-year limitations period for most claims arising under preenactment federal statutes as to which no clear rule of federal law has emerged.

We present our position in two parts. Part I proposes an alternative to the standard critique of $\S 1658$. Instead of chiding Congress for having failed fully to implement the recommendations of the Federal Courts Study Committee, Part I focuses on what Congress did accomplish in the face of obstacles that might have made a full legislative response difficult. In particular, Part 1 contends that the array of likely interest group opposition to legislation proposing to alter established limitations periods would have made the statute far more difficult to enact, particularly in the time available. This part concludes that $\S 1658$ makes a variety of important (and largely overlooked)

under statutes in effect as of December 1990; instead, they have borrowed from other sources. See International Ass'n of Machinists v. Tennessee Valley Auth., 108 F.3d 658, 661 n.4 (6th Cir. 1997) (noting that $\S 1658$ does not apply to claims arising under the Tennessee Valley Act, a fedcral statute that wis already in place as of $\S 1658$ 's effective date in December 1990); Providence Sch. Dep't v. Ana C., 108 F.3d 1, 1 n.1 (1st Cir. 1997) (Individuals with Disabilities Education Act); Barajas v. Bermudez, 43 F.3d 1251, 1255 n.3 (9th Cir. 1994) (Migrant and Seasonal Agricultural Worker Protection Act); Dell v. Board of Educ., 32 F.3d 1053, 1058 n.11 (7th Cir. 1994) (Individuals with Disabilities Education Act); Wolsky v. Medical College, I F.3d 222, 223 (4th Cir. 1993) (Rehabilitation Act of 1973); Shanahan v. Board of Educ., 953 F. Supp. 440, 442 (N.D.N.Y. 1997) (Individuals with Disabilitics Education Act); Doukas v. Metropolitan Life Ins. Co., 882 F. Supp. 1197, 1200 n.4 (D.N.H. 1995) (Americans with Disabilities Act); see also Kurinsky v. United States, 33 F.3d 594, 599 (6th Cir. 1994) (refusing to apply the four-ycar period of $\S 1658$ on the ground that the claim in question arose under a statute already in effect as of December 1990 and borrowing a state law limitations period instead); Halkias v. General Dynamics Corp., 31 F.3d 224, 239-40 (5th Cir. 1994) (applying the federal six-month limitations period instead), vacated, 56 F.3d 27 (1995), aff'd, 101 F.3d 698 (1996); Hickey v. Irving Indep. Sch. Dist., 976 F.2d 980, 982-83 (Sth Cir. 1992) (applying the state law period instead); Middleton v. Russell Group, Ltd., 924 F. Supp. 48, $51-52$ (M.D.N.C. 1996) (rejecting the argument for the application of $\S 1658$ to a claim under ERISA and applying state law instead); Curtis K. v. Sioux City Community Sch. Dist., 895 F. Supp. 1197, 1220-21 (N.D. Iowa 1995) (recognizing that $\$ 1658$ does not control the timeliness of claims arising under a preenactment statute but drawing support for the selection of a relatively longer state limitations period from the "duration and rationale" of $\S 1658$ ); $c f$. Lampf, Pleva, Lipkind, Prupis \& Petigrow v. Gilbertson, 501 U.S. 350, 363-64 \& n.10 (1991) (dismissing $\S 1658$ as "obviously" inapplicable to claims that both accrued before December 1990 and arose under statutes then on the books); Siniscalchi v. Shop-Rite Supermarkets, Inc., 903 F. Supp. 182, 188-89 \& n.5 (D. Mass. 1995) (noting that $\$ 1658$ does not apply directly to statutes enacted before 1990 but nonetheless suggesting a possible application of the stutute to such claims). For the Supreme Court's most recent teaching on the subject, reaffirming the primacy of limitations periods borrowed from state law, see North Star Steel Co. v. Thomas, 515 U.S. 29 (1995). 
contributions to our law of federal limitations, contributions that more than adequately vindicate the congressional decision to refrain from taking up thorny timeliness questions concerning preenactment statutes.

Part II turns to consider the process by which federal courts should fashion judge-made limitations periods in the wake of the adoption of $\S 1658$. After criticizing the current regime of state law borrowing, this part argues for a shift to presumptive reliance on uniform federal limitations periods. In particular, this part suggests reliance on the four-year limitation of $\S 1658$-a default provision that would work for most outstanding issues. Such an approach, we emphasize, rests entirely on the federal courts' retained power to fashion federal common law and not on a claim that Congress itself extended the fouryear period to claims under preenactment statutes. We thus base our argument on the model of retained federal common-lawmaking authority practiced in Moragne v. States Marine Lines, Inc. ${ }^{17}$ and not on any argument from legislative intent.

We do not understand Congress to have foreclosed this approach. Credible legislative history suggests that the congressional rejection of retroactivity meant to preclude only the reopening of those periods that had been fixed with relative certainty as of 1990 . As to the remainder of unsettled issues, Congress understood that the process of fashioning federal common law ought to continue. While Congress meant to preserve settled limitations periods by limiting the reach of its residual statute, it did nothing to require the federal courts to apply state law limitations periods to other, unsettled, settings. In other words, federal courts should not view the legislation as a directive to borrow state law to solve all limitations problems.

\section{RETHINKING THE STANDARD CRITIQUE OF $§ 1658$}

\section{A. The Standard Critique of $\S 1658$}

Section 1658 grew out of dissatisfaction with the Supreme Court's rule of routine reliance upon state law to provide the measure of the timeliness of federal rights of action. ${ }^{18}$ Following years of academic and judicial criticism of the state law borrowing regime, ${ }^{19}$ the Federal Courts Study Committee recommended abolition of borrowing. ${ }^{20}$ In its place, the Study Committee recommended that Congress specify the following: a particular limitations

17. 398 U.S. 375 (1970) (holding that enactment by Congress of spectic wrongful death statutes for maritime deaths did not displace the Court's retaned power to overrule the well-established judge-made rule barring recovery of tort damages for injuries resulting in death)

18. See supra notes $7-8$ and accompanying text

19. For effective criticisms of the state law borrowing regime, see Nelson, supra note 14, at $466-86$. and Norwood, supra note 14, at 480-502.

20. See REPORT, supra note 8. 
period to govern every new federal right of action that it legislates into existence, particular limitations periods to govern the rights of action already on the books as to which it had failed to specify limitations periods, and a fallback limitations period that would govern the timeliness of any actions for which it failed to set a particular period. ${ }^{21}$ In arguing for such new legislation, the Study Committee cited a variety of familiar concerns, including the difficulty of the task of judicial borrowing, the lack of certainty and predictability, and the incentives for forum shopping. ${ }^{22}$

Section 1658 appeared shortly after the Study Committee published its final report in April 1990 and owes much to the efforts of Representative Bob Kastenmeier of Wisconsin. Kastenmeier served both as a member of the Study Committee and as chair of the House Subcommittee on Courts, Intellectual Property, and the Administration of Justice, the Subcommittee that took responsibility for drafting legislation to implement the report. ${ }^{23}$ Kastenmeier worked with his staff to cull from the committee's recommendations those suggestions that, as he later described the process in his opening remarks at the hearing on the bill, would prove the easiest to enact and the most "noncontroversial." ${ }^{24}$ Little time remained before Congress adjourned, ending the 101 st Congress, and only the least controversial provisions would clear the House in time to join provisions in a Senate bill that was expected to appear before the end of the session in October. ${ }^{25}$

Reflecting the goals of avoiding controversy and moving quickly, section 112 of the bill dealt with the problem of federal limitations periods in terms similar to those that now appear in $\S 1658 .{ }^{26}$ In particular, the Subcommittee version of the bill established a residual four-year limitations period for federal rights of action adopted in the future but did nothing to address the problem of the timeliness of federal claims arising under preenactment statutes.

Although the bill's failure to address the timeliness of claims under preenactment statutes attracted critical comments from many of the witnesses who testified at the September hearing, ${ }^{27}$ the House Subcommittee ultimately

21. See REPORT, supra note 8 , at 93 .

22. See id.

23. See Nelson, supra note 14 , at $499-500$ (noting Kastenmeier's role in the development of the legislation).

24. Hearings, supra note 1, at 82 (statement of Rep. Kastenmeier) (describing the process by which Kastenmeier and Rep. Carlos Moorhead identified the recommendations in the Study Committee report that were "regarded as sufficiently noncontroversial to be implemented in the limited time that remained in this Congress").

25. See id. at $82-83$ (describing the introduction of the House version of the Senate bill as occurring at Sen. Joseph Biden's request and noting the controversy that surrounded the bill).

26. The draft bill, H.R. 5381, 101st Cong. (1990), included as section 112 the fallback limitations period that became $\$ 1658$. See Hearings, supra note 1 , at 9 (reprinting section 112).

27. See Norwood, supra note 14, at 505 (citing submissions to the House Subcommittec by Judges Deanell R. Tacha and Joseph F. Weis, Jr., and by representatives of the Department of Justice and the public interest group Public Citizen, all supporting the extension of the four-year limitations period to claims under preenactment statutes). 
decided to retain this feature of the provision. ${ }^{28}$ The House Report tells the story as follows:

Witnesses testifying on behalf of the Department of Justice and the Judicial Conference, urged that this section be made retrospective, so as to provide a fallback statute of limitations for previously enacted legislation lacking a limitations period. As witness George Freeman noted at the hearing, however, with respect to many statutes that have no explicit limitations provision, the relevant limitations period has long since been resolved by judicial decision, with the applicable period decided upon by the courts varying dramatically from statute to statute. Under these circumstances, retroactively imposing a four year statute of limitations on legislation that the courts have previously ruled is subject to a six month limitations period in one statute, and a ten year period in another, would threaten to disrupt the settled expectations of a great many parties. Given that settling the expectations of prospective parties is an essential purpose of statutes of limitation, the Committee was reluctant to apply this section retroactively without further study to ensure that the benefits of retroactive application would indeed outweigh the costs. ${ }^{-y}$

The report thus cites a concern with the disruption of settled expectations in explaining the Subcommittee's decision to ignore the critics and proceed with a prospective solution. The action of the House Subcommittee proved decisive, and the final terms of $\S 1658$ follow the prospective structure developed by Congressman Kastenmeier.

Academic observers have consistently rejected the argument from settled expectations as a justification for the action of the House Subcommittee. Professor Kimberly Norwood, the statute's leading academic critic, argues that the Subcommittee's concems with retroactivity and settled expectations do not justify the congressional refusal to extend the four-year limitations period to claims under existing statutes. ${ }^{30}$ Professor Norwood notes that Congress could have fashioned a fallback limitations period for claims arising under existing statutes and could have solved any retroactivity problem by making the statute applicable only to claims that accrue after its effective date." Such an accrual

28. As the excerpt from the House Repor reveals. see infra text sccompanying nute 29. the tetention of the prospective feature of the statute represented, at least in pant. a decision to credit the concerns ot George Freeman, Jr., who testified, "The very reasons for having a uniform Federal statule of limitations where none is presently specified is to provide certainly and predictability But making il setruscuive is counter to those very principles." Hearings, supra note l, at 246 (statement of Geurge C Freeman, Ir . Chair, ABA Business Law Section).

29. H.R. REP. No. 101-734, at 24 (1990), repruted in 1990 U S C C A N 6860, 6870

30. See Norwood, supra note 14, at 506-08 (arguing that no retroatuvily problem would have resulted from a decision by Congress to create a general four-ycar limitations penod for clams urising under statutes already on the books in December 1990 and to apply the statute only to clatms ansing after the effective date of the statute).

31. See id. at 506-07. 
approach would have addressed any conceivable concern of the institutional defendant: All such defendants could prospectively adjust as needed to conform to the new limitations period that would henceforth govern claims under preenactment statutes. Norwood concludes that the congressional rejection of the proposed creation of a fallback limitations period for claims under such statutes was "startling," both because it rejected the Study Committee's recommendation and the weight of thoughtful testimony and because it did so on the basis of a groundless concern. ${ }^{32}$ Other academic critics of the statute share Norwood's view that Congress faced no substantial problem of retroactivity. ${ }^{33}$

The shared view that Congress could have solved the retroactivity problem has fed the perception that Congress failed to do its job, leading to a call for Congress to revisit the issue and supply the missing limitations periods. ${ }^{34}$ Although we agree that an accrual approach might have surmounted the retroactivity problems, we do not fully accept the standard critique and do not share the view that Congress necessarily must legislate again.

\section{B. Rethinking the Standard Critique of $\S 1658$}

Our disagreement with the standard account stems from our sense that interest group considerations may explain why Congress framed the statute as it did. Interest groups have long played a central role in academic accounts of the legislative process, although portraits of their influence vary from the beneficent to the pernicious depending on the model of the legislative process one selects. ${ }^{35}$ Much of the period immediately following World War II was characterized by a relatively benign conception of the role of interest groups, a conception that followed from a public-spirited view of the role of legislators. ${ }^{36}$ More recently, public choice theorists have offered a more

32. See id. at 507.

33. See, e.g., Nelson, supra note 14 , at 507-09 (discounting the House's concern with retroactivity and proposing a solution similar to Professor Norwood's).

34. See Norwood, supra note 14, at 517-18 (proposing the congressional enactment of a new four-ycar limitations period for all claims, express or implied, arising under acts of Congress that lack express periods and including accrual language to address the problem of retroactivity); see also Nelson, supra note 14, at 509-11 (discussing the difficulty of persuading Congress to provide statute-by-statute limitations periods and proposing instead a general four-year limitations period to govern existing rights of action).

35. See ABNER J. MiKVA \& ERIC LANE, Legislative PRocess 18-25, $542-44$ (1995) (summarizing the debates over public choice and interest group pluralism).

36. Legislators, in this model of interest group pluralism, act as ideologically motivated public servants who conscientiously attempt to develop rules for a good society, while interest groups present competing conceptions of the public good. By forging compromises among competing views, legislators were thought to produce good policy outcomes. For an overview of the model of interest group pluralism that scemed to dominate academic treatments of the legislative process in the 1950 s, see William N. Eskridge, Jr. \& Philip P. Frickey, Statutory Interpretation as Practical Reasoning, 42 STAN. L. REV. 321 (1990). On the role of Professors Hart and Sacks in the development of the legal process school, see William N. Eskridge, Jr. \& Philip P. Frickey, An Historical and Critical Introduction to Legal Process, in HENRY M. HART \& ALBERT M. SACKS, The Legal Process (William N. Eskridge, Jr. \& Philip P. Frickcy cds., 1994). 
cynical account of the motivation of legislators and a more jaundiced assessment of the influence of interest groups. ${ }^{37}$

Whatever one's conception of the role of interest groups in American politics, common sense suggests that proposals to create, lengthen, or shorten statutes of limitations will attract fairly close attention from the affected interest groups. In general, we would expect the interests of plaintiffs and defendants to diverge, with the former preferring lengthy limitations periods and the latter preferring shorter ones. Beginning with this obvious (and rather banal) postulate, it follows that legislators who take up the task of formulating appropriate statutes of limitations will face an array of competing interests and conflicting pressures. On balance, consumer advocates-such as Public Citizen and various environmental groups-will tend to support relatively lengthy limitations periods, whereas business groups and other institutional defendants-such as the National Association of Manufacturers, the Chambers of Commerce, and lobbyists for small businesses-will tend to support shorter ones.

For one relatively clear example of the influence of prospective defendants in the drafting and enactment of advantageous statutes of limitations, consider the amendments to a 1990 statute of limitations that the Illinois General Assembly adopted in March 1995. The 1990 statute subjected claims of attorney malpractice to a six-year statute of repose, running from the date of the act or omission. ${ }^{38}$ But the 1990 repose provision included a proviso that excepted claims arising from "the death of the person for whom the professional services were rendered"; for such claims, the proviso created specific time limits that ran from the date of the client's death (apparently on the theory that many victims of malpractice in estate planning would not discover the wrong until after the initiation of probate proceedings or a will contest). ${ }^{39}$ The 1995 amendment struck the proviso from the statute, apparently in an effort to extend the benefits of the repose provision to attorneys who commit malpractice in the course of providing such estate planning advice. By eliminating the proviso, the amended version of the statute appears to shield estate planners from liability any time their clients live more than six years after the estate planning services were provided and fail to discover the attorney's malpractice during the intervening period. Not

37. For useful accounts of public chorce theory, soc DANIEL A FARBER \& PHILIP P FRICKEY. LAW AND PUBLIC ChOICE (1991); William N. Eskridge. Jr, Polincs Wrihout Romance Implicanons of Public Choice Theory for Statutony Interpretation, 74 VA. L REv 275 (1988). and Jonathan R Macey. Promonng Public-Regarding Legislation Through Statutory Interpresanon An Interest Group Model. 86 COLUM L REV. 223 (1986). For our critical reaction to this litcrature. see Abner J Mlikva. Foreword Sympostum on the Theory of Public Choice, 74 VA. L. REV. 167 (1988).

38. See Act of Mar. 9, 1995, Pub. Act No. 89-0007. \$ 13-214.3. 1995 Ill Laus 284, 308-09 (setung forth the text of 735 ILL. COMP. STAT. 5/13-214.3 (West 1994), the 1990 law governing the umeliness of attorney malpractice claims, as well as the amendatory changes of 1995)

39. See $\$ 13-214(d), 1995$ Ill. Laws al 308. 
surprisingly, the motivating force behind this change in the period of repose was the Section on Trusts and Estates of the Illinois State Bar Association. ${ }^{40}$

Interest group considerations like those that influenced the Illinois legislature may help to explain why the Kastenmeier bill addressed the problem of limitations in the terms chosen, rather than implementing the recommendations of the Study Committee. Recall that the Study Committee made three proposals: (1) that Congress create a prospective fallback limitations period (much like $\S 1658$ ) to fill gaps in any laws that future Congresses might enact without such periods; (2) that Congress cull through the United States Code and write limitations periods to govern all such rights of action that lacked such limits at the time; and (3) that Congress create a retrospective fallback limitations period to govern existing rights of action as to which no specific provisions were adopted. ${ }^{41}$ While such recommendations may have made eminently good sense from the perspective of the federal courts, which otherwise would have faced the messy business of gap-filling, their legislative implementation predictably would have attracted a great deal of interest group opposition.

An example from the House Report illustrates the problem. The Supreme Court's decision in DelCostello v. International Brotherhood of Teamsters ${ }^{42}$ borrowed a federal six-month limitations period for use in determining the timeliness of all "hybrid" duty of fair representation claims-the judge-made claims that disappointed grievants bring to challenge the results of the unionmanagement arbitration systems in place under many collective bargaining agreements. ${ }^{43}$ An attempt to reopen this settled time limit, through a proposal either to enact a specific limitations period for such claims or to make applicable to them a longer retrospective fallback period, predictably would have attracted the opposition of both labor and management. Significantly, the House Report included the six-month period established in DelCostello on its list of the limitations periods that its prospective approach to $\S 1658$ would not affect. ${ }^{44}$

This example illustrates how interest group considerations may have made the House reluctant to include any retrospective solution to the problem of state law borrowing in a statute meant to avoid controversy. Although everyone agrees that state law borrowing makes little sense and wastes judicial

40. See William A. Pleithmann, The Case for Amending the Attorney's Malpractice Law-and an Urgent Call for Help, TRusts \& EsTATEs (Illinois State Bar Ass'n, Section on Trusts and Estates), Sept. 1994, at 1 (advocating the extension of the benefits of the six-year repose provision to estate planners through elimination of the 1990 proviso and requesting help from other concerned lawyers in the effort 10 influence the legislative process). In fairness, we note that other groups have obtained the benefit of periods of repose, as Mr. Pleithmann observes in his article. See id. at 2-3 (describing periods of repose in Illinois law that benefit doctors, accountants, architects, and manufacturers).

41. See supra text accompanying note 21 .

42. 462 U.S. 151 (1983).

43. See id. at 169 .

44. See H.R. REP. No. 101-734, at 24 (1990), reprinted in 1990 U.S.C.C.A.N. 6860, 6870. 
time-after all, the recommendation emerged from the Judicial Workload Subcommittee of the Federal Courts Study Committee and thus appears to have reflected concerns about the waste of judicial resources-such good government considerations rarely attract concented interest group support for perfectly understandable reasons. The saving of judicial time will primarily operate for the benefit of the judges themselves-a group institutionally unsuited to exercise political clout in Congress-and for society at large. Without any interest group support, such good government legislation has been difficult to enact despite the efforts of public-regarding legislators. Coupled with clear and concentrated opposition, the absence of support makes the decision to remove all retrospective features from a bill designed to avoid controversy understandable.

Such interest group considerations help to highlight the incompleteness of the academic critique of the decision to make the statute applicable only to newly enacted statutes. As noted above, academic critics emphasize the House Report's reference to the disruption of settled expectations as the likely reason for the final prospective structure of the legislation and note that careful drafting could have addressed the issue of settled expectations." But such an explanation fails to perceive that any legislative tampering with established, albeit judge-made, limitations periods might have attracted the opposition of well-organized interest groups. Such organized opposition would have presented more than a mere drafting problem. It would have threatened the ability of the House Subcommittee to address the problem of limitations at all, especially in the time available.

The House Report's stated concern with the disruption of settled expectations may in fact have reflected worries about interest groups and what they would do. The House had good reason to worry that changes to clearly established limitations periods would attract organized opposition. In 1989, Kastenmeier had introduced a residual or fallback limitations period of ten years in length that would have applied to both subsequently enacted and existing statutory rights of action.to Professor Nelson reports that this provision attracted opposition and never reached the House floor. ${ }^{77}$ At the hearings one year later, Kastenmeier drew on this experience in emphasizing the importance of avoiding controversy; his 1990 bill reduced the residual limitations period from ten to four years and chose to address the limitations problem prospectively. These changes did not pass without notice; a representative of the American Bar Association's Standing Committee on Federal Judicial Improvements commented favorably on Kastenmeier's

\footnotetext{
45. See supra notes $30-33$ and accompanyung text

46. See H.R. 3553, 101 st Cong. (1989).

47. See Nelson, supra note 14, at 499 \& n 296
} 
decision to shorten the limitations period from ten years to four. ${ }^{48}$

Interest group pressures may also help to explain why the House seriously considered the comments of the one witness who expressed concern with retroactivity, George Freeman. ${ }^{49}$ Although the limitations periods for rights of action under preenactment statutes could have been addressed in ways that would have avoided retroactivity, Freeman may have been signaling opposition to the prospective alteration of settled limitations periods. Freeman represented the interests of the Business Law Section of the American Bar Association and thus spoke for the kinds of institutional defendants most likely to have opposed any statute that proposed to lengthen an established limitations period. In some respects, because of the $\mathrm{ABA}$ mantle, Freeman represented a more moderate opposition to changes than might have surfaced if the proposal had sought change in established limitations.

On the whole, the legislative record reveals that interest groups did participate in the legislative process in a fairly predictable manner. For starters, a representative of the public interest group Public Citizen testified in favor of the proposal to make $\S 1658$ fully applicable to claims arising under existing statutes $^{50}$ - a position consistent with the notion that the four-year period specified in the statute would be relatively generous to consumers, at least in comparison to many of the judge-made periods that otherwise would apply, and would provide a measure of certainty and predictability. Similarly, in opposing such an extension of the four-year period, Mr. Freeman espoused a position that served the interests of business groups and other institutional defendants, who would prefer shorter, and less clearly defined, judge-made periods. (Although both groups pay a price, the risks associated with uncertain limitations periods bear more heavily on plaintiffs, who face dismissals on the merits, than on defendants, who face some loss of repose.) Although the record reveals no evidence that members of the House faced any substantial armtwisting from the competing interest groups, it does suggest the ways in which interest group pressures may have helped to shape the development of the prospective terms of $\S 1658$.

Such an interest group account of the final terms of $\S 1658$ means that the legislation may have been more successful than it first appears. The passage of any legislation whatsoever reflects in good measure the skill of

48. See Hearings, supra note 1, at 242 (statement of Robert Landis, Former Chair, ABA Standing Committee on Judicial Improvements) (describing the ABA Standing Committee as "pleased" with the reduction).

49. See id. at 246 (comments of George C. Freeman, Jr.) (expressing concern with a growing trend toward retroactive legislation and concluding by "strongly urg[ing]" Congress to reject the proposed application of $\S 1658$ to existing rights of action as improperly retroactive and likely to undermine the goals of certainty and predictability).

50. See id. at 224 (statement of Alan Morrison, Director, Public Citizen Litigation Group) ("In our view, the general statute of limitations ought to apply to all cases, and not be limited to laws passed by Congress after the effective date of [the Act]."). 
Representative Kastenmeier in avoiding language that would have altered settled time limits and attracted serious and organized opposition. Once one recognizes that Kastenmeier may have viewed the real choice before the House as one between a relatively safe prospective statute of the kind enacted and a more risky, retrospective approach that may have attracted opposition, one can forgive the House for its failure to address existing limitations problems.

Section 1658 makes several important contributions to the law governing the creation of new limitations periods for federal claims. First, the new statute imposes an important discipline on future Congresses by establishing a fouryear limitations period as a default rule. ${ }^{51}$ Every statutory right of action created after December 1990 will include a limitations period-either a tailormade provision adopted by the enacting Congress or a four-year limitations period supplied by $\S 1658$. (In theory, of course, Congress might enact a new federal right of action that both fails to specify a tailor-made period of limitations and explicitly specifies that the fallback period of four years does not apply as the measure of timeliness. If such a statute were to appear, a remote prospect, federal courts might well read it to preclude the application of any limitations period to the claims in question, rather than as a directive to return to state law borrowing.) Many federal judges have criticized Congress for its failure to supply such limitations periods in the past; Judge Posner went so far in one opinion as to recommend the creation of a superagency watchdog to ensure that Congress includes a limitations period with all new rights of action. ${ }^{52}$ Section 1658 supplies the relevant assurance without the creation of such a watchdog.

The structure chosen by Congress makes sense in light of the history of previous efforts to fashion a residual limitations period and the opposition that various interest groups would have raised had Congress sought to move further. Relatively diffuse groups of consumers will experience more difficulty than their more concentrated institutional counterpars in devoting resources to influence the outcomes of legislation before Congress. ${ }^{53} \mathrm{~A}$ relatively generous four-year default rule makes sense in such a world because it assigns the burden of legislative inertia to the group best able to overcome the problems associated with effective lobbying. ${ }^{54}$ To obtain shorter, more advantageous limitations periods, institutional defendants will have to persuade Congress to insert specific time periods in statutes. Such a requirement of open dealing will benefit consumer groups by providing them with information they might

51. See Nelson, supra note 14, at 503-04 (discussing $\$ 1658$ 's lunction of plating Cungress un nuticx)

52. See Shor v. Belleville Shoe Mfg. Co.. 908 F2d 1385. 1395 (7th Cir 19x6) (Pusner. J. concurring).

53. See supra text following note 37

54. Cf. Ian Ayres \& Roben Geruncr, Filling Gaps in Incomplete Coniracis An Econumic Theon of Default Rules, 99 YALE L.J. 87, 94 (1989) (arguing that deldult rules may mstler in terms of the information they transfer from repeat to nonrepeat players in a (ransittion) 
otherwise lack about the presumptively applicable four-year period and by providing them with a bargaining chip for use in subsequent negotiations. The four-year default provision thus establishes a framework for future lobbying that correctly obliges institutional defendants to pursue advantageous outcomes openly.

In contrast, a short default period of, say, one year would provide a different and less appealing framework for future legislative deliberations. Institutional defendants would doubtless know of the one-year period, and they would have little incentive to seek more advantageous time limits through specific provisions. Without such information, relatively more diffuse consumer groups might fail to learn that the fallback limitations period favors institutional defendants and might fail to seek legislative specification. One can readily understand, therefore, why Congress refrained from adopting a proposal to establish a one-year fallback limitations period during the 1940s. ${ }^{55}$

Apart from these structural considerations, the four-year period identified in $\S 1658$ makes fairly good sense as an all-purpose limitations period for civil actions. One cannot, of course, develop (or defend) a particular limitations period through a purely logical process; one can only survey comparable limitations periods and use them as benchmarks with which to develop a rough idea of workable lengths for corresponding or analogous limitations periods. Such a survey reveals three benchmarks offering rough support for the fouryear period in $\S 1658$. First, Congress had previously adopted a five-year residual statute of limitations for federal criminal proceedings. ${ }^{56}$ Second, Congress had established a catch-all or residual five-year limitations period for suits brought to enforce federal penalties. ${ }^{57}$ The four-year period for civil claims in $\S 1658$ makes a certain amount of sense against the backdrop of these somewhat analogous five-year periods. Third, we have reviewed an unpublished, but relatively comprehensive, survey of federal limitations periods for civil actions. The survey, by Professor Peter Raven-Hansen, computes the average federal limitations period as three to four years in length. ${ }^{58}$

55. The 79th Congress rejected as too short a proposed one-year general limitations period for civil actions. See Developments in the Law-Statutes of Limirations, 63 HARV. L. REV. 1177, 1268 n.754 (1950) (reporting the rejection of a proposed one-year limitations period following an assertion by the Attorncy General that such a period was too short for claims arising under federal laws of trademark, copyright, civil rights, and antitust).

56. See 18 U.S.C. $\S 3282$ (1994).

57. See 28 U.S.C. $\$ 2462$ (1994) (stating that "[e]xcept as otherwise provided by Act of Congress, an action, suit or proceeding for the enforcement of any civil fine, penalty, or forfeiture, pecuniary or otherwise, shall not be entertained unless commenced within five years"). For a discussion of the statute's applicability to penalty and forfeiture actions on behalf of the federal government and its inapplicability to private civil litigation, see Carie Goodman McKinney, Note, Statute of Limitations for Citizen Suts Under the Cleait Water Act, 72 CORNELL L. REv. 195, 205-06 (1986).

58. See Raven-Hansen, supra note 12 , at $43-44$ (citing a survey of some 150 federal statutes of limitations that computed their average length to be three to four years). 
To be sure, these benchmarks stop well shor of proving that Congress picked out the "right" fallback limitations period. Determination of the "right" period presents an imponderable empirical challenge, given the variety of situations in which limitations concerns might arise. We have been unable to locate any evidence of which factors Congress actually relied upon in making its choice of four years. Yet the analogies help to confirm that the four-year period actually chosen rests comfortably within the range of workable solutions. Even if Congress stumbled on the four-year period, its choice at least was made in a process of prospective legislation that moderated the interest group pressures that have influenced the selection of other, more particular, limitations periods.

The simple fact that Congress established a residual or fallback limitations period also means that we can consider the four-year period as properly applicable to a wide variety of civil actions without worrying unduly that the provision does not properly balance the competing interests of plaintiffs (who seek access to court for adjudication of rights) and defendants (who seek repose and immunity from suit). By its terms, the residual pernod in $\$ 1658$ applies to all civil actions as to which Congress does not otherwise specify a limitations period. The four-year period thus applies across the board to virtually any kind of civil action Congress might conceivably create. While one can defend the period chosen for its structural implications for future lobbying and for its correspondence to other relevant measures of timeliness, much of the value of the statute derives from the simple fact that Congress has now chosen a generally applicable limitations period.

Finally, congressional adoption of a fallback four-year limitations period represents an important legislative acknowledgement that the regime of state law borrowing no longer makes sense, if indeed it ever did. The recommendation of the Study Committee rested on the claim that the regime of state law borrowing imposed a significant and unjustifiable burden on federal judges. ${ }^{59}$ Section 1658 emerged from a Congress that accepted this critique and sought to address the problem to the extent possible and within the time available in a manner that would avoid interest group opposition. To be sure, Congress enacts statutes rather than policies; one cannot predicate a change in the rule of state law borrowing on policies said to inhere in $\$ 1658$. Nevertheless, the congressional rejection of state law borrowing, coupled with the congressional provision of a generally applicable, natuonally uniform faliback limitations period sets the stage for the final abandonment of the current regime of presumptive-and irrational-reliance upon state law.

59. See supra text accompanying note 8 


\section{TOWARD a REgime of Nationally Uniform Federal Limitations PERIODS: THE RELEVANCE OF FEDERAL COMMON LAW}

Section 1658 plainly ends state law borrowing for claims arising under federal statutes first enacted after December $1,1990 .{ }^{60}$ It could also lead to the end of the regime of state law borrowing as applied to rights of action under federal statutes that were already on the books on that date. True, Congress left that area untouched by the statute; but as the branch of government responsible for the rule of state law borrowing, the federal judiciary may reconsider the doctrine. We believe that the federal courts retain their power over the content of the rules of federal common law that determine the timeliness of claims arising under such preenactment statutes. The Supreme Court could and should use these retained common law powers to establish a regime of presumptive reliance upon federal limitations periods. Nothing Congress did in the 1990 statute precludes such a result.

\section{A. Federal Common Law and the Inadequacy of the Court's Proffered Justifications for State Law Borrowing}

The Supreme Court has long chosen to fashion rules of federal common law as the measure of the timeliness of federal rights of action for which Congress has failed to specify a particular limitations period. The practice of judicial gap-filling began in Adams $v$. Woods, ${ }^{61}$ a decision by the Marshall Court, continued throughout the nineteenth century, ${ }^{62}$ and today still commands the support of Justices across the spectrum of views on issues of federal common law and judicial gap-filling. ${ }^{63}$ Even Justice Scalia-the most ardent opponent of judicial innovation in areas thought to lie within congressional competence ${ }^{64}$-accepts the idea that federal courts should routinely fill the gaps that result from the failure of Congress to specify

60. See supra text accompanying notes 10-11.

61. 6 U.S. (2 Cranch) 336 (1805).

62. See, e.g., Campbell v. Haverhill, 155 U.S. 610 (1895) (applying a six-year tort limitations period from state law to a federal patent claim within the exclusive jurisuiction of the federal courts); $c f$. M'Cluny v. Silliman, 28 U.S. (3 Pet.) 270 (1830) (applying an Ohio statute of limitations to a state-created trespass action brought in federal court against a federal officer).

63. See North Star Steel Co. v. Thomas, 515 U.S. 29 (1995) (holding unanimously that state law limitations periods govern federal claims under the Worker Adjustment and Retraining Notification Act); cf. Agency Holding Corp. v. Malley-Duff \& Assocs., 483 U.S. 143, 157-65 (1987) (Scalia, J., concurring) (stating that state law applies of its own force as the measure of timeliness, unless preempted by conllicting federal law); DelCostello v. International Bhd. of Teamsters, 462 U.S. 151, $172-74$ (1983) (Stevens, J., dissenting) (arguing that the Rules of Decision Act compels reliance on state law limitations periods to fill gaps in federal statutes).

64. See, e.g., Thompson v. Thompson, 484 U.S. 174, 189-91 (1988) (Scalia, J., concurring) (arguing against judicial "creation" of implied rights of action and advocating an absolute rule against the recognition of rights of action absent an explicit provision in the text of a statute). 
limitations periods for federal rights of action and should do so by applying limitations periods drawn from noncongressional sources."

In addition to broad agreement on the propriety of gap-filling, the Justices generally agree that the federal courts should look to analogous state law limitations periods as the primary or presumptively applicable measure of the timeliness of federal claims. In North Star Steel Co. $v$. Thomas, ${ }^{07}$ the Court unanimously held that state law furnished the rule of timeliness to govern actions to enforce rights under the Worker Adjustment and Retraining Notification (WARN) Act. In the course of its decision, the Court reaffirmed its "longstanding"" commitment to presumptive reliance upon state law to fill the gap created by a missing federal limitations period. ${ }^{\text {as }}$ The Court recognized that it has occasionally borrowed periods of limitations from analogous federal statutes. ${ }^{69}$ It emphasized, however, that borrowing from federal sources remains an exception to the rule of primary reliance upon state law. ${ }^{70}$ Borrowing from federal sources comes into play only where otherwise applicable state limitations periods would "'frustrate or interfere with the implementation of national policies"'?1 or where the federal rule would provide a "'significantly more appropriate vehicle for interstitial lawmaking."'"72

Despite its reaffirmation in North Star Steel, the rule of primary reliance on state law rests on relatively weak foundations. In the leading case from the nineteenth century, Campbell v. Haverhill, ${ }^{73}$ the Cour relied upon sheer necessity to justify its application of a state law limitations period. Congress had previously supplied a six-year limitations period for patent claims ${ }^{74}$ but had failed, in the course of recodifying the statute, to specify a time limit for infringements occurring after 1874. Confronted in Campbell with one such unrestricted claim, the Court filled the gap by borrowing a state law limitations period identical in length to that which Congress had previously applied to the

65. See Agency Holding Corp., 483 U.S. at 157-65 (Scalta. J , concumng) (ubserving that statc law limitations periods routinely apply in cases where Congress has (alled (o specify limitutions periods)

66. With but one exception, the Coun has viewed the fulure of Congress to specilly a limitatuons period as an invitation to the federal courts to borrow a gaphllet from some other suurce The lune exception is Occidental Life Insurance Co. vEEOC. 432 US 355 (1977), which relusad to burruu $\downarrow$ limitation after concluding that Congress meant to leave government clasms to enlorce Tule VII unrestricted. Cf. Agency Holding Corp., 483 U S. at 170 (Scalis. J concurnng) (suggestıng that where federal interests preclude the application of state limitations penods federsl couns should relisin trum borrowing a federal period and refuse to apply any limitations penod at all)

67. 515 U.S. 29 (1995).

68. Id. at 1931 (quoting Agency Holding Corp. 483 U S at 147)

69. See id.

70. See id.

71. Id. (quoting DelCostello v. Intemational Bhd of Teamsters. 462 L'S 151. 161 (1983) (quoung Occidental, 432 U.S. at 367)).

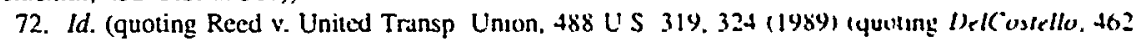
U.S. at 172)).

73. 155 U.S. 610 (1895).

74. See Act of July 8,1870 , ch. 230,16 Stat 198. 206 
federal patent rights at issue. ${ }^{75}$ The Court justified its decision to apply state law on the ground that the absence of any limitations period would of fend the rule of law, quoting with approval the decision by Chief Justice Marshall in Adams $v$. Woods ${ }^{76}$ which characterized temporally unlimited federal rights of action as "utterly repugnant to the genius of our laws." 7

Although its prudential concerns came through clearly enough, the Campbell Court was hard pressed as a theoretical matter to justify its reliance upon state law. The Marshall Court had filled the gap in Adams, after all, by borrowing a limitations period from federal law and had seemingly refused to consider the possible applicability of state law. ${ }^{78}$ Marshall's implicit rejection of state law was consistent with the then-current conception of statutes of limitations as matters of procedure ${ }^{79}$ and with the Marshall Court's subsequent refusal in Wayman v. Southard ${ }^{80}$ to countenance state regulation of the practice and procedure of federal courts. ${ }^{81}$ Foreclosed by such theoretical barriers from arguing that state law applied of its own force, the Campbell Court chose to rely instead on a claim that Congress, through the Rules of Decision Act, ${ }^{82}$ had directed the federal courts to incorporate state law to fill gaps in federal statutes. ${ }^{83}$ But while the inflexible command of the Rules of Decision Act could explain the application of state law to patent claims within the exclusive jurisdiction of the federal courts, it could not solve all of the Court's problems. For as the Campbell Court went on to observe, the Act did not require the federal courts to apply state statutes of limitations that were unduly short or that discriminated against the enforcement of the federal

75. See Campbell, 155 U.S. at 613-14.

76. 6 U.S. (2 Cranch) 336 (1805).

77. Id. at 342; Campbell, 155 U.S. at 616-17.

78. See Adams, 6 U.S. (2 Cranch) at 336. The two-year federal limitations period in Adeans applicd by its terms to fines or forfeitures sought by way of information; the statute said nothing about actions in debt to recover a penalty. Chief Justice Marshall nonetheless held that the two-year period applied. See id. at 342. No one appears to have suggested that some state law limitations period for actions in debt ought to have applied to the proceeding, even though such applicability would have eliminated the argument for stretching the federal statute.

79. See JOSEPH STORY, COMMENTARIES ON THE CONFlict of LAWS $482-83$ (Boston, Charles C. Litule \& James Brown $2 \mathrm{~d}$ ed. 1841) (stating that "statutes of limitation . . . are strictly questions affecting the remedy, and not questions upon the merits" and therefore must be determined by reference to the law of the forum); see also Sun Oil Co. v. Wortman, 486 U.S. 717 (1988) (relying upon the traditional characterization of limitations periods as matters of procedure in upholding the power of state courts to apply their own limitations periods to claims with which they have little contact other than as the forum state).

80. 23 U.S. (10 Wheat.) 1 (1825).

81. See $i d$. at 49 (holding that the inability of state legislatures to claim jurisdiction over federal procedure is "one of those political axioms, an attempt to demonstrate which, would be a waste of argument not to be excused").

82. 28 U.S.C. $\$ 1652$ (1994).

83. See Campbell, 155 U.S. at 614-15; cf. Agency Holding Corp. v. Mulley-Duff \& Assocs., 483 U.S. 143, 157-65 (1987) (Scalia, J., concurring) (arguing that Campbell supports his claim that state law limitations periods apply by their own force in cases where Congress has failed to specify a limitations period). 
rights at issue. ${ }^{84}$ What the Court ultimately sought was a flexible warrant for fashioning limitations periods according to the circumstances of the particular case.

Post-Erie ${ }^{85}$ decisions locate that warrant in the power of federal courts to fashion federal common law, but they do little to explain the Courts preference for state law as the source of borrowed limitations periods. As the Court explained in Holmberg 1 : Armbrecht, state limitations periods apply to federal claims, not of their own force and not by virue of the Rules of Decision Act, but only by virtue of their "implied absorption ... within the interstices of the federal enactments" through the process of fashoning federal common law. ${ }^{87}$ It follows that the Cour remains free to borrow a federal limitations period in appropriate cases; indeed, since Holmberg, the Court has borrowed from federal sources on at least three occasions. ${ }^{36}$ But despite its own recognition that it may borrow from federal sources, the Coun has largely failed to justify its continuing adherence to a rule of primary reliance on state law. ${ }^{89}$

One might try to justify the Court's rule by likening its preference for state law to its traditional willingness to consider the interests of the states in the course of deciding whether to create federal common law in other fields. In Boyle v. United Technologies Corp., ${ }^{90}$ for example, Justice Scalıa's decision to fashion a federal contractors' defense had to overcome an argument in favor of deferring to traditional state control over the definition of ton law." Similarly, in United States v. Kimbell Foods, Inc.," the Court decided to

84. See Campbell, 155 U.S at 615 (emphastang that the relerence lo stale laws ds tules of dicwion "in cases where they apply" may give the federal courts "s centun discretion with respect to the enforcement of state statutes").

85. Erie R.R. v. Tompkins, 304 U S. 64 (1938) (declanng that the lederal courts must spply stalte fules of decision, rather than general federal common ldw, to resulve dispules ansing frum state-crested clutms!

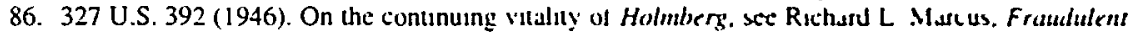
Concealmem in Federal Court: Toward a More Disparate Standard'. 71 Gro L J 529 11983,

87. Holmberg, 327 U S at 395; see also DelCostello y Interndtuonal Bhd of Tesmstets, 462 L' S 151. 160 \& n.13 (1983) (explaining that netther Erie nor the Rules of Deciston Act compels the applitatlun of state law limitations periods to claums crealed by Congress for which Congress lallod lo speall! + particular period).

88. See Lampf, Pleva, Lipkind, Prupis \& Petugrow 、 Gilbertson. 501 L'S 350 11以9l I apply ing a limitations period from elsewhere in lederal secunties law 10 medsure the umeliness of xitun $106-5$ claims); Agency Holding Corp., 483 U S at 143 (applying the four-year limitations pernexd in (la) (un Act

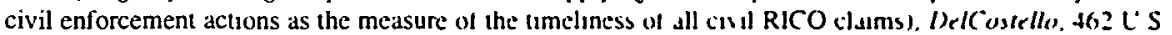
at 151 (applying the Labor Act's six-month limudtions petiod for untalt lator practice latms as the

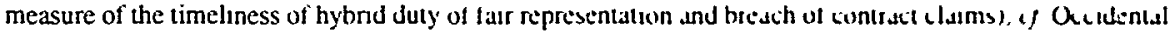
Life Ins. Co. v. EEOC, 432 U.S. 355 (1977) (holding that no statule of limitations applies lo clatnis brugght by the EEOC to enforce Tule VII and interpreung congressiund stlence ds tejecting state law borruw ing for claims brought by the tederal government)

89. See North Star Sicel Co. v Thomas. 515 l'S 29. 34 (1945) (dosubing ladcral burruwing as a closely circumscribed and narrow exception to the rule of promaly relance on stale law)

90. 487 U.S. 500 (1988)

91. See id. at 515-31 (1988) (Brennan. J dissenung) (crillulang the majority on thuth xeparation of powers and federalısm grounds).

92. 440 U.S. 715 (1979) 
subordinate the priority of liens arising from federal programs to the state's interest in the application of internally consistent rules of priority for competing creditors. ${ }^{93}$ Many commentators agree that the interests of the states ordinarily deserve at least some consideration in the decision whether to fashion federal common law. ${ }^{94}$

In contrast to cases like Boyle and Kimbell Foods, however, the states have little discernible interest in the application of their rules of timeliness to federal rights of action. States enjoy presumptive control over any field of government regulation that Congress has not occupied, but this interest in preserving control as against federal preemption does not apply with any force to the determination of the timeliness of rights of action that have been, by definition, created by federal law. Unlike the situation in Boyle, where Congress's refusal to create a federal defense for government contractors made the argument for continued state control somewhat more difficult for the majority to ignore, the regime of state law borrowing comes into play only when Congress has (explicitly or implicitly) created federal rights enforceable in federal courts. State regulatory primacy thus offers little support for a regime of presumptive reliance upon state law limitations periods.

Similarly, states have little interest in the application of internally consistent time limits to federal claims, many of which do not readily conform to existing state law categories. Consider, for example, the question of which limitations period should govern claims by disappointed union members who wish to challenge both their discharge as a breach by their employer of the collective bargaining agreement and the handling of their grievance as a breach of their union's federal duty of fair representation. Many federal courts struggled with this question, analogizing the collective bargaining agreement claim to one brought under state contract law and the duty of fair representation claim to one of legal (or other) malpractice; other federal courts saw the claims as tantamount to efforts to vacate an arbitration award and applied relatively short time limits. ${ }^{96}$ Whatever the proper characterization, the sheer variety of possible analogies and the inability of state courts to secure uniformity through control over the development of the law serves to reduce substantially any state interest in the uniform application of state rules of

93. See id. at 740 .

94. See, e.g., Henry J. Friendly, In Praise of Erie-and of the New Federal Common Law, 39 N.Y.U. L. REV. 383, 410 (1964).

95. See Boyle, 487 U.S. at 504-14.

96. Compare United Parcel Serv., Inc. v. Mitchell, 451 U.S. 56 (1981) (applying a state law limitations period for an action to vacate an arbitration award to an employee's challenge to the legality of the arbitral award under a collective bargaining agreement), and UAW v. Hoosier Cardinal Corp., 383 U.S. 696 (1966) (applying a state law limitations period for contract claims to a suit brought by the union to enforce a collective bargaining agreement), with DelCostello v. International Bhd. of Teamsters, 462 U.S. 151 (1983) (overnling Mitchell implicitly and substituting a federal six-month limitations period for an employec's claim against both the employer and the union). 
timeliness. Stronger arguments support the development of nationally uniform rules of timeliness to govern such claims. ${ }^{97}$

In the absence of any state interest in the application of state limitations periods to federal rights of action, the Court has turned to other justifications for the current regime. As we noted above, ${ }^{98}$ the Court has defended state law borrowing on grounds of necessity by repeating its view that unrestricted federal claims would be "'utterly repugnant"' to the rule of law." If this argument from utter repugnance can justify a federal judicial role, it can hardly justify a rule of presumptive reliance on state law. Borrowing from federal sources would avoid the problem of the temporally unrestricted claim just as effectively as state law borrowing; indeed, the Court originally deployed the argument from utter repugnance to support borrowing from federal sources. ${ }^{100}$

Apart from this claim of necessity, the Court has defended its current approach by reference to a construct of presumed legislative intent. ${ }^{101}$ In effect, the Court holds that its willingness to fashion judge-made limitations periods in the past justifies the continuing creation of judge-made periods in the future; the Court's rule of state law borrowing operates as an interpretive rule for handling cases of omitted limitations periods and gives rise to reliance interests on the part of Congress and interest groups. A decision to abandon such judicial setting of limits might unfairly surprise legislators (or institutional defendants and their lobbyists) who reasonably relied on the continued application of the rule in question.

Such stare decisis considerations cannot justify continued and constant adherence to a rule of state law borrowing. The sheer variety of potentially applicable state limitations periods makes it extremely difficult for members of Congress or lobbyists to predict with any confidence what period of limitations would apply to any particular statutory right of action that Congress has chosen to create. Even if such certainty existed at the time the legislation was enacted in one or more states or federal judicial circuits, subsequent

97. See DelCostello, 462 U.S. at $158-72$ (developing a uniform federal six-month limitutuons penod for hybrid actions against employers and unions and concluding thall conflucting state limitations penous were an unsatisfactory vehicle for the enforement of federal law)

98. See supra text accompanying notes $76-77$

99. Campbell v. Haverhill, 155 U.S. 610.616.17 (1894) (quoung Adams y Woods. 6 U S (2 Cramh) $336,342(1805))$.

100. See supra text accompanying note 78 (discussing the ratuonale of Chuel Justuce Marshull's decision in Adams, 6 U.S. (2 Cranch) 336 (1805)).

101. See North Star Steel Co. v. Thomas, S15 U.S. 29. 34 (1995) (noung that "'11 is not only appropriate but also realistic to presume that Congress was thoroughly familiar with [our] precedents ... and that it expect[s] its enactment|s] to be interpreted in conformity with them "' (quotung Cannon v. University of Chicago, 441 U.S. 677.699 (1979))). DelCosiello. 462 U S at 158 ("We huve generally concluded that Congress intended that the cours apply the most elosely analogous statute of limitations under state law."); Campbell, 155 U.S. at 616 ("Is it not more reasonable to presume that Congress, in authorizing an action for infringement, intended to subject such action to the general laus of the State applicable to actions of a similar nature? . . [M] Just we not presume that Congress intended that the remedy should be enforced in the manner common to like actions withen the same junsdiction ${ }^{\prime \prime}$ ) 
changes in relevant state limitations periods may well alter the time periods in question. In any case, many federal rights of action arise from the congressional regulation of transactions in interstate commerce-transactions that often give rise to the possibility of litigation in more than one state. In light of the uncertainty surrounding the locus of litigation, interest groups and members of Congress would have great difficulty building a case of reliance on the basis of the claimed applicability of any particular state limitations period. The construct of presumed legislative intent thus resembles the argument from "utter[] repugnan[ce]"102 in that it supports continued judicial gap-filling but not continued reliance upon state law.

Even this attenuated "presumed intent of Congress" argument for state law borrowing does not appear to survive the enactment of $\S 1658$. As we saw earlier, the creation of the fallback four-year federal limitations period in $\S 1658$ establishes a new default rule that will structure the lobbying and legislative processes for the foreseeable future. Congress and interest groups now know that the failure to insert a specific limitations period into a federal statute that creates a new right of action will result in the application of the four-year period. In other words, no member of Congress or interest group can base a claim of reasonable reliance on the willingness of the federal courts to supply limitations periods by reference to state law. As a prospective matter then, the Court simply cannot justify continued adherence to a rule of state law borrowing by reference to its construct of "presumed intent."103

We believe that $\S 1658$ substantially undermines the regime of state law borrowing. First, the statute implements a vision of federal uniformity and simplified limitations-setting much at odds with the complexity of the current regime. Second, $\S 1658$ establishes a structure for future lobbying that eliminates any stare decisis justification for the maintenance of the status quo.

\section{B. Toward a Regime of Federal Uniformity in Borrowed Limitations Periods}

Just about every observer agrees that a regime of uniform federal limitations periods would outperform the current presumption in favor of borrowing from state law. As we noted at the beginning of this Essay, ${ }^{104}$ reliance upon state law requires federal judges to survey an array of potentially applicable state limitations periods and to choose the most analogous period for application to a federal right of action that contains no such period. Such a regime exacts substantial process costs, as courts and litigants struggle to identify the most analogous limitations period in state law or, if no good state analogies exist, to select the appropriate federal limitations period. In addition,

102. Campbell, 155 U.S. at 616 (quoting Adams, 6 U.S. (2 Cranch) at 342).

103. See North Star Steel, 515 U.S. at 34 n.* (recognizing that arguments from presumed intent do not apply to statutes enacted after the effective date of $\$ 1658$ ).

104. See supra note 6 and accompanying text. 
the regime results in the development of limitations penods that may vary dramatically from state to state. Such variability introduces capriciousness and a lack of uniformity into federal law and creates obvious incentives for forum shopping as litigants vie for differing periods. ${ }^{10 s}$ Presumptuve rellance upon federal law limitations periods would help to solve many of these problems.

But presumptive use of federal sources would not solve all problems. Even in a world where state law limitations periods were eliminated from the calculus, complexity and uncertainty would remain. Litigants would presumably continue to identify a wide array of analogous federal limitations periods for courts to consider. Some continuing variability would persist as the product of federal judicial disagreement over which statute offered the closest analogy to the particular case. ${ }^{106}$ Apar from uncerainty and vanability, reliance upon federal analogies would project one federal limitations period into a different and unanticipated context. Such projections cause the greatest conceptual difficulty in cases where relatively particularized interest group considerations appear to have influenced the congressional selection of the limitations period proposed for use as an analogy. A perıod chosen by Congress to accommodate competing interest groups in the field of antutrust litigation, for example, may not accommodate the different groups affected by the assertion of civil RICO claims. ${ }^{107}$ Judges understand the existence of these problems of projection in theory but lack practical tools with which to calibrate their impact in a regime of borrowing. ${ }^{\text {los }}$ The Cour's continuing adherence to a rule of state law borrowing may reflect its perception that a switch to federal law borrowing might not constrain the judicial process sufficiently to gain much by way of simplicity or cerainty. Cerrainly, Justice Scalia's image of federal courts and litigants "prowling hungrily" through the federal law books in search of analogies does not seem far from the mark. ${ }^{104}$

105. For an overview of these problems, sec Norwood. supra note 14. 4 t 480.502 Ser also Vielsun. supra note 14, at 466-86.

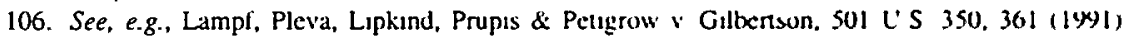
(applying a uniform federal one-year-from-discovery, three-year-repose limitatuons penod and rejectung $\perp$ five-year limitations period drawn from elsewhere in (ederal secunucs laws). Agency Holdung Curp 、 Malley-Duff \& Assocs., 483 U.S. 143, 155-56 (1987) (applying a untorm foderal lour-year limututions period to civil RICO claims and rejectung an analogy to a federal five-year penod for craminal prosecutions under RICO).

107. But cf. Agency Holding Corp., 483 U.S at 143 (applying the four-yedr limituluons penod irom the Clayton Act, which govems private suits to enforce the antitrust laws. Io prwate cond RICO enforcement proceedings).

108. For recognition of the problems of projection entalled in borrowing a limitations period irom one compromise for use in a different field with diffenng interest group considerations, see Short a Belleville Shoe Manufacturing Co., 908 F.2d 1385, 1393 (7th Cir 1990) (Posner. J . concurring). which expluns that the regime of borrowing "runs the nsk of applying one unprincipled legislatue deal to a prublem enturcly outside the scope of the deal."

109. Agency Holding Corp., 483 U.S. at 166 (Scalad, J. concumng) (charactenang the mujurtiy. in its decision to borrow a federal statute of limitations, as "prowling hungnly through the Statutes 4 Large for an appetizing" statute of limitations). 
Reliance on $\S 1658$ could help to solve these additional problems by providing a four-year period of limitations for use in most cases of congressional silence. As we have already seen, Congress chose the four-year period as a general purpose or fallback limitations period appropriate for use as the measure of timeliness for any civil action created by federal law. Its availability for use as the gapfiller in a variety of different federal statutes suggests that the four-year period can reduce the problems of complexity and uncertainty otherwise associated with regimes of borrowing. In addition, the four-year period of $\S 1658$ emerged from a process that was, by design, relatively free of interest group pressures. The absence of interest group pressures reduces the problems associated with the projection of the four-year period into other fields.

Despite the obvious attractions of the four-year residual limitations period of $\S 1658$, most assume that adopting it for claims arising under preenactment statutes would require further legislative action. As we noted in Part I, academics have criticized the statute's failure to address the serious problem of claims arising under preenactment statutes and argue for the passage of legislation tailored to such claims. ${ }^{110}$ Similarly, most federal judges who have faced arguments for the application of the four-year period to claims under preenactment statutes have dismissed such arguments out of hand. ${ }^{11}$ In contrast, we believe that the Supreme Court remains free, through the exercise of its power to fashion rules of federal common law, to create a regime of federal uniformity that would include substantial reliance on the four-year fallback as the presumptive period of limitations.

We base our argument on the model of federal common-lawmaking exemplified by Moragne v. States Marine Lines, Inc. ${ }^{12}$ Moragne holds that judge-made federal maritime law creates a right of action to recover damages for injuries resulting in the death of a longshoreman due to the "unseaworthiness" of a vessel plying territorial waters. ${ }^{13}$ Remarkably, Moragne asserted this authority over the content of federal common law in the face of two facts: that wrongful death actions traditionally had been regarded as creatures of statute and that Moragne's claim fell outside the scope of existing statutory schemes. ${ }^{114}$ One statute governed wrongful deaths on the high seas and another concerned wrongful deaths due to negligence, but none applied to the unseaworthiness claims of Mrs. Moragne. ${ }^{115}$ Rather than treating this legislative silence as dispositive of the particular claim before it,

110. See supra notes 14-15 and accompanying text.

111. See supra note 16.

112. 398 U.S. 375 (1970).

113. Id. at $395,407-08$.

114. See id. at $390-403$.

115. Or, as Judge Posner pithily put the matter after summarizing the array of inapplicable statutory remedies, Mrs. Moragne's claim "fell among all these stools." Richard A. Posner, Legal Formalism, Legal Realism, and the Interpretation of Statutes and the Constitution, 37 CASE W. RES. L. REV. 179, 201 (1987). 
the Court viewed itself as retaining control over the content of federal common law. ${ }^{116}$ After carefully reviewing the nineteenth-century origins of the rule against recovery for wrongful death, the Cour jettisoned the rule and allowed the action to proceed. ${ }^{117}$ The Court went further, however, suggesting that provisions borrowed from the (otherwise inapplicable) Death on the High Seas $\mathrm{Act}^{118}$ could govern the amount of the recovery available under the new right of action and the identity of the proper beneficiaries-questions that otherwise would have been difficult to answer judicially. ${ }^{119}$

Moragne establishes that the Court may reconsider a rule of federal common law that gave rise to the passage of a limited federal statute. The legitimacy of continuing judicial control over the content of federal common law offers a complete answer to those who would argue that the failure of Congress to address claims under preenactment statutes in $\S 1658$ forecloses any evolution in the rule of presumptive reliance upon state law that has long governed the timeliness of such claims. Moragne also makes clear that, having altered the underlying rule of common law, the Cour remains free to give content to its new rule by borrowing from the federal statute closest at hand. Moragne thus opens the way to a federal decision to establish a new common law rule of presumptive reliance upon federal law borrowing and of similar reliance upon the residual four-year limitations period of $\S 1658$ for use in measuring the timeliness of claims under preenactment statutes. Such a fouryear period would apply, not by virtue of congressional action, but as the result of the ongoing evolution of federal common law.

Although Moragne helps to answer most doubts as to the legitimacy of a judicial decision to modify the rule of borrowing by incorporating the four-year period of $\S 1658$, we should briefly consider a variety of plausible but ultimately unpersuasive arguments against our solution to the timeliness problem. To begin with, nothing in the text of $\S 1658$ forecloses the recognition of continuing federal common-lawmaking authority over borrowed limitations periods. By its terms, $\S 1658$ governs actions arising under statutes enacted after December $1990 .{ }^{120}$ For such actions, $\S 1658$ specifies a fouryear limitations period, except as otherwise provided by law. ${ }^{121}$ As to actions arising under statutes already on the books in December 1990, $\$ 1658$ has nothing to say. The statute does not speak about either the period of limitations for existing actions or the process by which the federal courts should fashion limitations periods to govern them.

116. See Moragne, 398 U.S. at 397-403.

117. See id. at $375,402-03$.

118. 46 U.S.C.A. $\$ 761$ (West 1975) (repcaled 1980)

119. See Moragne, 398 U.S. at 407-08.

120. See 28 U.S.C. $\$ 1658$ (1994).

121. See id. 
This legislative silence appears to leave the task of fashioning a federal common law of borrowed limitations periods in the hands of the federal courts. Certainly, the willingness of the Supreme Court to borrow from federal law sources in the wake of $\S 1658$ 's adoption suggests that the Court does not regard the statute as having frozen in place a regime of rigid reliance upon state law. ${ }^{122}$ Even the Court's recent reaffirmation of state law primacy stopped well short of foreclosing the future borrowing of federal limitations periods in appropriate cases. ${ }^{123}$ We simply argue here that the federal courts should borrow a federal rule in a broader range of cases.

To be sure, a strong textualist might quibble with any attempt on the part of the federal courts to fill gaps in federal legislation by borrowing a period of limitations from another source. Such a text-based refusal to fill gaps would force Congress either to legislate limitations periods for federal rights of action or to face the prospect that such claims would remain temporally unrestricted. But, as we have seen, even the Court's most devoted textualists have made their peace with the longstanding tradition of borrowing state law to fill such gaps. Once the textualist admits that federal courts may apply rules of timeliness other than those legislated into place by Congress, the question becomes not how to interpret the legislative text (which, of course, does not speak to the problem) but how best to fill the gap in federal law. In this area of more or less candid judicial lawmaking, congressional texts play a less significant interpretive role.

Legisprudes who believe (as we do) that legislative history can legitimately inform the interpretation of statutes may pose a more subtle challenge to our approach. These critics may rely upon negative implications said to flow from the explicit refusal of the House Subcommittee to extend the four-year limitations period of $\S 1658$ to federal actions then on the statute books. ${ }^{124}$ Such critics may contend that having failed to persuade Congress to act, the federal judiciary may not legitimately achieve by judicial decree what it had been unable to secure from the legislative process.

Although we agree that the House Report helps to explain why the Subcommittee framed the statute to apply prospectively, we do not believe that any negative implications from the Report foreclose our approach. For one thing, the Court rejected a stronger argument from negative implications in Moragne, where the failure of Congress to create a wrongful death action for unseaworthiness on the low seas can be said to have implied a congressional

122. See Lampf, Pleva, Lipkind, Prupis \& Petigrow v. Gilbertson, 501 U.S. 350, 356-60 (1991) (applying the one-year-from-discovery, threc-year-repose limitations period from elsewhere in the federal securities laws to govern implied rights of action under section $10(\mathrm{~b})$ and rejecting state law borrowing and periods from elsewhere in federal law).

123. See North Star Steel Co. v. Thomas, 515 U.S. 29, 34 (1995) (recognizing the possibility that periods drawn from federal law may better harmonize with the objective of the immediate cause of action).

124. See supra text accompanying note 29. 
design either to foreclose compensation for such claims or to leave the measure of any compensation to state law. In contrast, the House Report on $\$ 1658$ expresses concern not with the use of a four-year period of limitations per se but with its blanket use in circumstances that would disrupt settled expectations. ${ }^{125}$ It was the rigidity entailed in the legislative specification of four-year limitations periods for all claims that concerned the House, and it is because of this rigidity that the Report recommended further study to determine whether the benefits of such a blanket rule would indeed outweigh the costs.

Ultimately, then, the House Report expresses tacit, but nonetheless clear, approval for the principle that the federal courts should continue to fashion a federal common law of limitations periods. As outlined below, such a body of law might feature presumptive reliance on the four-year period of $\S 1658$ and remain sensitive to the interests of groups that have come to rely upon the existing state of the law. In some cases, such reliance factors will weigh in favor of the ongoing application of the limitations periods that the federal courts have previously borrowed to govern the timeliness of such claims. In many other cases, where the federal courts have failed to reach a consensus about the proper rule of timeliness, reliance interests will pose no substantial obstacle to the routine use of the four-year period.

Finally, the adoption of our proposed solution need not threaten the ability of Congress to structure prospective legislation in the future. One might argue that the retrospective application of a statute that Congress meant to apply prospectively might disable future Congresses from developing "noncontroversial" prospective legislation. Imagine a prescient member of Congress who objected to the Kastenmeier bill on the ground that the federal courts might adopt our solution and use the four-year period as the measure of timeliness for one or more of the existing claims that would have been seemingly unaffected by the prospective terms of the statute. Would such an objection have derailed the legislation? Obviously, we cannot say for sure. But Kastenmeier could have addressed the objection either by fixing a particular limitations period to address the member's concem or by adding language to the statute forbidding its use as a borrowed limitations period for some sensitive category of federal statutes.

Even if they agreed with the legitimacy of its judicial creation in the face of congressional silence, others might argue against our proposal for presumptive reliance upon a one-size-fits-all four-year period of limitations. Such critics of a uniform federal rule would build on the common sense idea that any particular period of limitations must strike a balance among an array of competing interests: the interest in protecting valid claims, the interest in prohibiting the prosecution of stale claims, the durability of the evidence, and 
the attitude of the legislature toward the claim. ${ }^{126}$ Such functional considerations may influence the legislative calculation of limitations periods to some degree: The periods for disfavored claims (like defamation) tend to be relatively short whereas periods for contract claims may vary depending on evidentiary issues, such as whether the contract appears in writing. ${ }^{127}$ Judge Posner identifies a host of similar variables in the course of arguing that no single, one-size-fits-all federal limitations period should apply to all claims. ${ }^{128}$ One might contend, building on Posner's claim, that the current regime of state law borrowing enables the courts to reach a more fine-grained judgment about the timeliness of federal claims than would a uniform rule.

For a variety of reasons, we do not believe such an argument for functionality can justify continued adherence to the rule of state law borrowing. To begin with, one surely can dispute the claim that the legislatively prescribed limitations periods for existing rights of action left unaddressed by $\S 1658$ ought to vary according to the nature of the particular claim. After a careful review of that problem, Professor Raven-Hansen rejected the argument for functional variability and instead proposed a general purpose four-year period of limitations for all such claims. ${ }^{129} \mathrm{He}$ did so for reasons we find persuasive: existing periods of limitations do not necessarily correspond to such functional factors; any functionality that once existed may have disappeared over time; problems of characterization would persist following the passage of such a statute; and the sheer number of unrestricted claims, which Raven-Hansen places at more than 200 , would make the task of drafting a functionally variable statute quite daunting. ${ }^{130}$ Professor RavenHansen in effect concludes that the argument for the recognition of nice theoretical distinctions must give way to arguments from necessity and convenience in the legislative creation of limitations periods. ${ }^{131}$

Arguments from necessity and convenience apply with greater force to the judicial creation of limitations periods in the wake of $\S 1658$. Unlike legislation that clearly applies throughout the country, judge-made rules percolate up from the bottom of the judicial hierarchy. Judicial efforts to create

126. See Wilson v. Garcia, 471 U.S. 261,282 (1985) (O'Connor, J., dissenting) (stating that limitations periods are not purely arbitrary); Johnson v. Railway Express Agency, 421 U.S. 454, 463-64 (1975) (stating that the period selected should reflect a balance between "the interests in favor of protecting valid claims" and the "interests in prohibiting the prosecution of stale ones").

127. See Wilson, 471 U.S. at 282 (O'Connor, J., dissenting) (arguing that differing periods for defamation and contract claims reflect an evaluation of the claims in light of the life expectancy of the evidence and the reasonable expectations of repose).

128. See Short v. Belleville Shoe Mfg. Co., 908 F.2d 1385, 1394 (7th Cir. 1990) (Posner, J., concurring) (identifying such factors as the rate at which evidence will decay, the opportunities for concealment, and the defendants' interest in repose as relevant in fixing the timeliness of particular suits and arguing that no single period of limitations would be suitable for the entire range of causes of action).

129. See Raven-Hansen, supra note 12.

130. See id. at $37-42$.

131. See id. at 37 ("'Statutes of limitation find their justification in necessity and convenience ... rather than principles."' (quoting Chase Sec. Corp. v. Donaldson, 325 U.S. 304, 314 (1945))). 
functional periods of limitations through the borrowing process thus entail greater uncertainty and unpredictability than similar efforts in the legislative branch. ${ }^{132}$ In any case, the task of selecting an appropriate state law analogy requires courts to consider a host of factors and to render a "standardless, discretionary judgment." 133 Justice Scalia and others have mounted persuasive arguments against such open-ended balancing and in favor of a rulebased jurisprudence. ${ }^{134}$ One need not fully accept Scalia's critique of balancing to agree that a rule makes more sense in this context; it was, after all, the uncertainty associated with balancing that led Congress to substitute the four-year rule of $\S 1658$ for state law borrowing in the first place.

Having disposed of the principal objections to presumptive borrowing from $\S 1658$, we now consider how the federal courts might implement such a regime to achieve a tolerable degree of certainty and predictability without disrupting settled expectations. We do not suggest that judges apply the fouryear period routinely and unthinkingly to every claim arising under the statutes on the books as of December 1990. After all, the refusal of Congress itself to address claims under preenactment statutes stemmed from its concern that the retrospective alteration of established limitations periods might disrupt settled expectations and do more harm than good. ${ }^{135}$ The federal cours can address these issues of settled expectations on a case-by-case basis within the following guidelines. Courts should give the greatest respect to expectational claims based upon limitations periods that the Supreme Cour itself has established in uniform rules borrowed from federal sources. Such nationally uniform rules, settled at the highest level, achieve the goals of certainty and uniformity and create expectation interests that deserve some measure of respect.

Rules of timeliness that rely upon state law borrowing are somewhat less deserving of continued application. Defendants, particularly those who limit their activities to a single state, might make a plausible case for reasonable reliance on rules that require the borrowing of state law limitations periods shorter than four years. In many cases, however, the claim of reliance will not withstand close scrutiny. So long as the defendants face a threat of multistate litigation, and so long as one state's limitations period equals or exceeds four years, the reliance claim is largely groundless. Moreover, so long as the proper state law analogy has not been settled by a decision of the Supreme Court,

132. See Short, 908 F.2d at 1394-95 (Posner, J., concurnng) (rejocing an argument lur judictal borrowing of state law limitations periods as unpredictable. expensive. and intestupubly arbitrary and arguing instead for a legislative solution).

133. Id. at 1394 (Posner, J., concurring).

134. See Antonin Scalia, The Rule of Law as a Law of Rules. 56 U CHI L ReV 1175 (1989). see also Louis Kaplow, Rules Versus Standards: An Economic Analisis. 42 Dukr. LI 557. 571.77 (1992) (arguing that rules can reduce enforcement costs in areas of repeated application)

135. See supra text accompanying note 29. 
uncertainty about the proper characterization would appear to defeat many claims of reliance.

The reliance interests of plaintiffs may deserve greater respect, at least in circumstances where tolerably clear rules call for the application of limitations periods longer than four years. A decision to shorten a relatively clear limitations period would result in the unexpected dismissal of the plaintiff's claim. Such unexpected dismissals end the case at a single stroke and thus exact a heavy toll on plaintiffs. No similar burden ordinarily falls upon defendants who face an unexpected lengthening of tolerably clear limitations periods. Only in rare cases can defendants show that their ability to mount a defense has been compromised by actions they took in reliance upon a shorter limitations period.

Our essentially common sense view that the reliance interests of plaintiffs deserve greater respect than those of defendants finds support in the rules of constitutional law that govern the legality of legislative changes in the applicable rules of timeliness. Generally speaking, defendants can constitutionally attack a change in a rule of timeliness only where it threatens to remove the bar of limitations after title to property has vested in them. Lacking any claim to a "vested right" in repose, most defendants cannot challenge legislative lengthening of limitations periods on constitutional grounds. In contrast, legislative shortening of established limitations periods may violate the due process rights of plaintiffs, at least to the extent that it threatens to extinguish otherwise viable claims. ${ }^{136}$

We do not see the Court's decision in Lampf, Pleva, Lipkind, Prupis \& Petigrow v. Gilbertson ${ }^{137}$ as contrary to our proposed rule of providing relief to plaintiffs from the application of an (unexpectedly short) four-year limitations period. To be sure, the Gilbertson Court applied its own newly established one-year-from-discovery, three-year-repose limitations period in dismissing claims by plaintiffs with solid reliance claims and specifically rejected an argument for equitable tolling. ${ }^{138}$ Yet the Court rejected the argument for tolling on narrow grounds of inconsistency with the specific terms of the three-year repose provision of the limitations period in question. ${ }^{139}$ Taken on its own terms, then, Gilbertson does not foreclose the

136. For general accounts of recent developments in the Court's management of issues of retroactivity in civil litigation, see Richard H. Fallon, Jr. \& Daniel J. Meltzer, New Law; Non-Retroactivif; and Constitutional Remedies, 104 HARV. L. REv. 1731 (1991); and Jill E. Fisch, Retroactivity and Legal Change: An Equilibrium Approach, 110 HARv. L. Rev. 1056 (1997). See also David M. Mark. Retroactivity of Statute of Linitations Rulings Under the Infuence of Jim Bcam, 29 IDAHO L. REV. 361 (1992-1993) (examining the influence of changes in the Court's retroactivity jurisprudence in the area of limitations law).

137. 501 U.S. 350 (1991).

138. See id. at 363-64.

139. See id. at 363. 
tolling of limitations periods, like the four-year period in $\S 1658$, lacking periods of repose.

Apart from the limited scope of the Gilbertson decision, the Court's own thinking seemingly has evolved away from the approach adopted by the narrow five-Justice majority in Gilbertson. The retroactive features of that decision not only attracted a persuasive dissenting opinion by Justice $O^{\circ}$ Connor. ${ }^{1+0}$ but also unsettled the expectations of a good many plaintiffs and eventually led to the passage of new legislation by Congress seeking to reinstate claims unfairly dismissed on its authority. ${ }^{141}$ All of these consequences of Gilbertson returned to the Court itself in Plaut v. Spendthrift Farms, Inc., ${ }^{\text {142 }}$ a decision that struck down one portion of the statutory fix as violative of the doctrine of separation of powers. ${ }^{143}$ Plaut came down one week before oral arguments in North Star Steel Co. v. Thomas, ${ }^{1+4}$ the case the Court used to announce its return to presumptive reliance on state limitations periods. We think it no coincidence that the state law presumption in North Star Steel resulted in the application of relatively generous state law limitations periods in preference to a much shorter, six-month period drawn from federal sources. The Courts unanimous rejection of an unsettlingly short federal limitations period in North Star Steel may well have reflected an enhanced appreciation of the unfortunate consequences, made evident in Plaut, of its rejection of the plaintiffs' plausible arguments for equitable relief in Gilbertson. The Court's experience in Gilbertson and Plaut suggests that many problems of unfair surprise that otherwise arise from judicial changes in periods of limitations can be avoided through the selection of the relatively generous four-year period of limitations in $\S 1658 .{ }^{145}$

To illustrate how our approach might affect the selection of limitations periods in future cases, we examine a series of recent Supreme Cour decisions and ask how the Court should address the issue of limitations periods in a future case presenting similar questions. Consider first such decisions as DelCostello, ${ }^{146}$ Agency Holding Corp..$^{1.7}$ and Gilbertson. ${ }^{1.8}$ In each case,

140. See id. at 369 ( $\mathrm{O}^{\circ}$ Connor, J., dissentung)

141. See Federal Deposit Insurance Corporation Improvement Act of 1991. Pub $\perp$ No 102.242. 5 476,105 Stat. 2236,2387 (codified at 15 U.S C $\$ 78 \mathrm{as}-1$ (1994))

142. 515 U.S. 211 (1995).

143. See id. at 225.

144. 515 U.S. 29 (1995).

145. Cf. Curtis K. v. Sioux City Communily Sch Dist . 895 F Supp 1197.1220.21 (.X D luws 1995) (drawing support for the selection of a relatively long limitutions peried trom the "Jut stiun and ratiunale" of $\S 1658)$.

146. DelCostello v. International Bhd. of Teamsters, 462 L'S 151. 169.72 (1983) (4pplying 4 nationally uniform six-month limitations penod to all hybnd clatms for bresch of a collextive bargatning agreement and breach of the duty of fair representation)

147. Agency Holding Corp. v Malley-Duft \& Assocs . 483 U'S 143. 156 (1987) (applyıng a lour-yeds limitations period from the Clayton Act to civil RICO clams)

148. Lampf, Pleva, Lupkind, Prupis \& Petigrow v Gilherison, S01 L'S 350. 361 .64 (1991) ( apply tng a limitations period, drawn from federal law, as the measure of the umeliness of insider trading clums under the securities laws). 
the Court established a nationally uniform limitations period by borrowing from a source elsewhere in federal law, and we see little cause to reconsider the periods actually chosen in light of the new four-year period of $\S 1658$. As we noted above, such nationally uniform limitations periods eliminate any incentive for forum shopping and achieve a significant degree of certainty and ease of application. In addition, the affected groups have presumably adjusted to these limitations periods or, as in the case of Gilbertson, have sought and obtained corrective legislation from Congress. ${ }^{149}$ Finally, prospective defendants in claims governed by DelCostello were among those most likely to have opposed legislative application of a general four-year period to claims under preenactment statutes. Indeed, the report explaining the House's decision to avoid retrospective application specifically mentions the six-month limitations period of DelCostello to illustrate the kind of limitations period that it wished to avoid unsettling. ${ }^{150}$ Little would be gained, and much uncertainty might result, from a decision to reopen these settled periods of limitations and to apply a new four-year period.

In contrast to their treatment of claims already subject to nationally uniform time limits, federal courts facing claims arising under the WARN Act plant closing legislation should apply a uniform, federal four-year period borrowed from $\S 1658$. To be sure, the North Star Steel decision applied the presumption in favor of state law borrowing and rejected the defendant employer's proffered six-month federal limitations period. The Court, however, found it unnecessary to provide a definitive characterization of the federal claim at issue for state law borrowing purposes, noting only that the plaintiffs' claims were timely under the two state law analogies proposed by the parties. ${ }^{151}$ It thus remains uncertain exactly how the federal courts will characterize WARN Act plant closing claims. In addition, opportunities for forum shopping and multistate variability abound in the plant closing area, and with them comes a heightened need for a nationally uniform rule. For example, the claims involved in North Star Steel itself arose from a plant closing in Alabama, but the plaintiffs chose to file suit in Pennsylvania. ${ }^{152}$ These two sources of variability - variability due to characterization questions and variability in state law-will doubtless continue to confound lower court judges and litigants and create incentives for forum shopping. Federal courts could simplify matters considerably by adopting a uniform federal rule and could do so without upsetting the expectations of defendants.

149. For a summary of the legislative response to Lampf, see Plaut v. Spendihrift Farms, Inc., 515 U.S. 211, 214-15 (1995), which reviewed the congressional attempt to reestablish old limitations periods to protect the reliance interest of plaintiffs.

150. See supra text accompanying note 29.

151. See North Star Steel Co. v. Thomas, 515 U.S. 29, 35 (1995).

152. See id. at 32. 
As the preceding paragraph suggests, the Court bears ultimate responsibility for the content of the rules of federal common law that will fill the gaps in $\S 1658$. Pending further guidance from the Court, the lower federal courts may legitimately borrow the four-year limitations period of $\S 1658$ for use in some situations. Established law already permits the federal courts, on occasion, to borrow from federal sources; North Star Steel explicitly reaffirmed the viability of such borrowing even as it reaffirmed the primacy of state law. While the lower federal courts might understandably hesitate to move away from the North Star Steel presumption in favor of state law, they nonetheless can find in particular cases that the North Star Steel presumption has been rebutted and that federal law applies. The availability of a readymade four-year limitations period might conceivably expand the circumstances in which the lower federal courts would find the presumption favoring state law to have been overcome.

For a satisfactory solution to the problem of timeliness in the face of congressional silence, however, guidance must come from the Supreme Court itself. Our proposed use of the four-year period of $\$ 1658$ derives much of its appeal from the promise of consistency, cerainty, and ease of application. Lower federal courts cannot achieve those goals through occasional borrowing from $\S 1658$. If some courts refuse to borrow from $\S 1658$, the resulting interdistrict and inter-circuit variability would preserve the very uncertainty that our proposal seeks to overcome. Only a decision by the Cour, establishing a fairly strong presumption in favor of borrowing from the uniform four-year period of $\S 1658$, can furnish the promise of national uniformity that this comer of the law so obviously needs.

\section{CONCLUSION}

We share the concerns of those who have criticized the existing regime of state law borrowing and those federal judges who understandably view the borrowing process as largely wasted motion. The selection of a period of limitations has an arbitrary quality and does not lend itself to the process of reasoning by analogy. It is better to have a fixed period than an elegant body of nuanced doctrine that yields considerably different answers depending on the judge, the state, or the characterization of the federal claim. In a perfect world, Congress would have addressed all these concerns when it took up the limitations problem in 1990.

Many argue that efforts to solve the problem of borrowed hmitations should focus on securing further legislation from Congress. Such an avenue certainly deserves exploration, but Congress may find it difficult to offer much more guidance in this area. Congress responds to specific demands from constituents and interest groups and has a great many issues on its plate. In our world of scarce legislative resources, the press of other business may make it 
difficult for Congress to revisit the problem. The messy interest group considerations that we explored in Part I help to explain why, despite the good work of Professor Raven-Hansen and the recommendations of Professor Norwood, Congress has made little progress in defining particular limitations periods for rights of action under preenactment statutes. In truth, Congress may have given all the help it can on these questions.

Instead of awaiting further legislative action, the federal courts can and should solve their own problems by invoking their retained authority over the content of the rules of federal common law that govern judge-made statutes of limitations. The rule of state law borrowing developed as a rule of federal common law; Congress did not impose it upon the courts. The federal courts thus retain full control over the content of the body of common law and, under the theory of Moragne v. States Marine Lines, Inc., ${ }^{153}$ can modify the rule in light of changed circumstances. Indeed, circumstances certainly have changed. State law borrowing began before the explosion of complex federal statutes in the twentieth century, at a time when the federal courts had no general or residual limitations period to apply to federal claims. The rule makes far less sense today in a world where the process of drawing analogies to state law has grown more complex, the connection of federal claims to particular states has grown more tenuous, and the federal courts have available to them a plausible four-year limitations period that can serve as an appropriate measure of the timeliness of many federal civil actions. Nothing in the action that Congress took in 1990 precludes the courts from reviewing the area in which Congress did not act.

The nominal predicate for retaining the rule-the stare decisis concerns embedded in the Court's construct of presumed legislative intent-simply cannot support continued state law borrowing. Section 1658 now frames the legislative process prospectively, and the courts are free and ought to be willing to address the issue of limitations periods for actions arising under preenactment statutes. Other reliance interests may deserve respect, such as the interests of those who have come to rely upon clearly established judge-made rules of timeliness. As we have shown, however, the federal courts can respect such interests as occasional departures from a framework of presumptive reliance upon limitations periods drawn from federal law or through the application of principles of equitable tolling. Congress should not be held solely responsible for cleaning up the preexisting mess. It has already made a commendable house-cleaning in the area of limitations law. 